\title{
Optimization of cultural conditions for production of antifungal metabolites by Streptomyces gougeroti
}

\author{
Mohamed Abodobara ${ }^{1}$, Amira El-Falal ${ }^{1}$, Mohamed Mousa ${ }^{1}$ and Enas Shaaban*1 \\ ${ }^{1}$ Department of Botany \& Microbiology, Faculty of Science, Damietta University, New Damietta, Egypt. \\ Received: 1 November 2020 /Accepted: 26 November 2020 \\ * Corresponding author's E-mail: enas.shaaban8@gmail.com
}

\begin{abstract}
Use of antagonist microorganisms against fungal plant pathogens is an attractive and ecologically alternative to the use of chemical pesticides. Streptomyces spp. are beneficial soil bacteria and potential candidates for biocontrol agents. Different Streptomyces species were isolated from different sources sites from soil in Damietta.

During primary and secondary screening, some actinomyctes isolates showed antifungal activity against tested phyto pathogenic fungi (Penicillium italicum, Macrophomina phaseolina, Fusarium oxysporium, F. solani, Alternaria alternata, Sclerotina sclerotiorum and Rhizoctonia solani). The results showed that the most active isolate against tested phyto pathogenic fungi Macrophomina phaseolina and Alternaria alternata was identified as Streptomyces gougeroti. Streptomyces gougeroti showed maximum antifungal activity against Alternaria alternata and Macrophomina phaseolina at $35^{\circ} \mathrm{C} \pm 2, \mathrm{pH} 6.5$. Glycerol and beef extract were the best carbon and nitrogen sources used respectively.
\end{abstract}

Keywords: Streptomyces gougeroti, Macrophomina phaseolina, Alternaria alternata and Antifungal activities.

\section{Introduction}

Fungal plant diseases are a major concern to worldwide agricultural production. Plant diseases are a major problem facing plant cultivation and are responsible for the loss of 10 $\%$ of the total global crop production (Strange and Scott, 2005). Pathogenic fungi can generate thousands of microspores in lesions and lead to considerably increased propagation in similar hosts that could give way to split the diseases (Giraud et al. 2010). Fungi, one of the most aggressive plant pathogens, are conventionally destroyed with chemical fungicides. Their widespread use, which has tripled over the last 40 years, has accelerated environmental pollution and degradation. Moreover, chemical fungicides may be lethal to beneficial insects and microorganisms populating the soil and may enter the food chain (Budi et al. 2000). With all the problems associated with synthetic chemicals, many scientists are investigating biological pesticide solutions (Martinez 2012; Nega 2014). Biological pesticides include chemicals derived from microorganisms, plants and animal sources. Fungal infections are the main cause of postharvest rots of fresh fruit and vegetables during storage, transport and cause significant economic losses in the commercialization phase (Gatto et al. 2011). 
Infections caused during postharvest conditions lowers the shelf life and adversely affect the market value of fruits (Tripathi et al. 2008). Moreover, mycotoxins the secondary metabolites produced by fungi have adverse effects on humans and animals (Zain 2011).

Biological control, the use microorganisms to control plant diseases, offers an alternative, environmentally friendly strategy for controlling phyto pathogens (Kishore et al. 2005; Prapagdee et al. 2008; Sharma et al. 2011). The potential use of microorganisms in the treatment of plant fungal diseases is based on the antagonistic nature of microbes towards the fungal pathogens. The results of experimental and field trials studies of microbial antagonistic against plant fungal pathogens are promising (Sharma et al. 2009; Williams 2009).

Various microbial antagonists have been investigated as potential antifungal biocontrol agents of plant diseases. Many species of actinomycetes, especially those belonging to the genus Streptomyces are well known as biocontrol agents that inhibit or lyse several soils borne and airborne plant pathogenic fungi (El-Tarabily 2006; Lee et al. 2008; Sousa et al. 2008).

Many strains of Streptomyces are known to suppress fungal growth in vitro (Crawford et al. 1993). Streptomyces species or their products have been used to suppress fungal plant diseases in vivo (You et al. 1996; Liu et al. 1995). The objectives of this study were to study the optimization for antifungal activities by Streptomyces gougeroti against Alternaria alternata and Macrophomina phaseolina.

\section{Material and methods}

\section{Isolation of Streptomyces sp.}

The dilution agar plating technique described by Johnson et al., (1959) was used for isolation of Streptomyces sp. Starch- nitrate medium was used for isolation and purification of Streptomyces sp. (Waksman, 1959). The plates were incubated at $28^{\circ} \mathrm{C}$ for seven days.

\section{Growth of fungal strains}

Fungal strains, Alternaria alternata was isolated and identified by Prof El-Fallal and Macrophomina phaseolina. These strains were grown in Potato- dextrose agar medium at $30{ }^{\circ} \mathrm{C}$ for five days. The discs of agar cultures $(6 \mathrm{~mm}$ diameter) were used separately to inoculate 250 $\mathrm{ml}$ conical flasks containing potato- dextrose agar medium and poured in petri- dishes to examine the anti-fungal activities of tested Streptomyces strains.

\section{Preparation of metabolites from the tested isolates}

After the incubation period, cultures were harvested by centrifugation at $4,000 \mathrm{rpm}$ for 10 minutes. Culture supernatants were immediately transferred and filtered through Millipore filter $(0.45 \mu \mathrm{m})$ to get cell free supernatant. The remaining supernatants were used for the determination of intracellular protein.

\section{Determination of intracellular protein}

Harvested pellets were washed three times with distilled water. Washed pellets were centrifuged at 4,000 rpm for 10 minutes, washed and dissolved in $20 \mathrm{~mL}$ of $\mathrm{NaOH}(1 \mathrm{M})$, and boiled for 20 minutes. Boiled pellets were allowed to cool and then centrifuged at 4,000 rpm for 10 minutes. Dilution of the clarified solution was used to determine the intracellular protein concentration of the organisms using the BioRad protein assay (Bradford 1976).

\section{Environmental factors affecting production of antifungal metabolites by Streptomyces gougeroti}

\section{Effect of different media}

The selected isolate was grown in different media including: starch nitrate broth, starchammonium sulphate broth, glycerol-yeast broth, glycerol-asparagine broth, starch-casein broth, Czapek-dox broth and CM-I broth. Flasks were incubated at $28^{\circ} \mathrm{C} \pm 2$ and at $150 \mathrm{rev} \mathrm{min}^{-1}$ for 7 days. Then the cultures were collected and centrifuged at $4000 \mathrm{rpm}$ for 20 minutes and the supernatants were immediately transferred and filtered through Millipore filter $(0.45 \mu \mathrm{m})$ to get cell free supernatant. Antifungal activities were assayed, supernatant were subjected to agar diffusion assay against Alternaria alternata and Macrophomina phaseolina to select the most appropriate media for production the antimicrobial agent; (Rabah et al. 2007). 


\section{Effect of incubation periods}

The selected isolate was grown in a liquid glycerol-yeast media (Waksman 1961) as a basal medium. Flasks were inoculated using spore suspensions and incubated at $28^{\circ} \mathrm{C} \pm 2$ at $150 \mathrm{rev}^{-1}$. After $3,4,5,6,7$ and 8 days, three flasks were harvested for each interval. Antifungal activity was assayed as before.

\section{Effect of different $\mathrm{pH}$.}

The selected isolate was grown in a liquid glycerol-yeast medium. The $\mathrm{pH}$ was adjusted at 5.0, 6.0, 7.0, 8.0 and 9.0. Flasks were inoculated with tested isolate and incubated at $28^{\circ} \mathrm{C} \pm 2$ for 5 and 4 days. Antifungal activity was assayed as before.

\section{Effect of different temperatures}

The tested isolate was grown in liquid glycerolyeast medium at $\mathrm{pH}$ 6.5. Flasks were inoculating with spore suspensions and incubation was carried out at 25, 30, 35 and $40^{\circ} \mathrm{C}$ for 4 days . Antifungal activity was assayed as before.

\section{5- Effect of different carbon sources}

Starch, cellulose and colloidal chitin were added separately $(1 \%)(\mathrm{w} / \mathrm{v})$ to liquid glycerol-yeast media and autoclaved with the media. Glucose, maltose, fructose and sucrose (1\%) (w/v) were added following sterilization by passing through Millipore filter $(0.45 \mu \mathrm{m})$ to liquid media.

The $\mathrm{pH}$ of the media was adjusted to 6.5 , then flasks were incubated at $35^{\circ} \mathrm{C} \pm 2$ for four days. Antifungal activity were assayed as before.

\section{6-Effect of different nitrogen sources}

A range of different nitrogen sources includes $\mathrm{NH}_{4} \mathrm{Cl}, \quad\left(\mathrm{NH}_{4}\right)_{2} \mathrm{SO}_{4}, \mathrm{NaNO}_{3}$ and asparagine were added in equimolecular nitrogen weights equivalent to the nitrogen content of $27 \mathrm{~g} \mathrm{~L}^{-1}$ peptone and yeast of glycerol-yeast media (Waksman 1961). Other nitrogen sources like peptone $(14 \% \mathrm{~N})$, yeast $(10 \% \mathrm{~N})$, casein $(14.5 \% \mathrm{~N})$, tryptone $(13.5 \%$ $\mathrm{N})$ and beef extract $(12.5 \% \mathrm{~N})$ were added.

The $\mathrm{pH}$ of the media was adjusted to 6.5 , then the flasks were inoculated and incubated at $35^{\circ} \mathrm{C}$ at $150 \mathrm{rev} \mathrm{min}^{-1}$ for four days. Antifungal activity was assayed.

\section{Results}

We isolated some strains of actinomycetyes from soil, most of these isolates showed high antifungal activities against tested phyto pathogenic fungi. We select the tested isolate that showed high antifungal activity against Macrophomina phaseolina and Alternaria alternata. This isolate was identified in previous work according to Bergey's Manual of Systematic Bacteriology- volume five the actinobacteria (Good Fellow et al. 2012) as Streptomyces gougeroti. Streptomyces isolate was grown on glycerol-yeast agar medium at $35^{\circ} \mathrm{C} \pm 2$.

The most producing medium for bioactive metabolites was glycerol-yeast extract medium as it promoted the highest bioactive potential against Alternaria alternata $(2.97 \pm 0.02 \mathrm{~cm})$ and Macrophomina phaseolina $(2.9 \pm 0.05 \mathrm{~cm})$. Starch-ammonium sulphate, glycerolasparagine, CM-I and Czapek-Dox media had no antifungal activity against the tested phytopathogenic fungi (Figure 1).

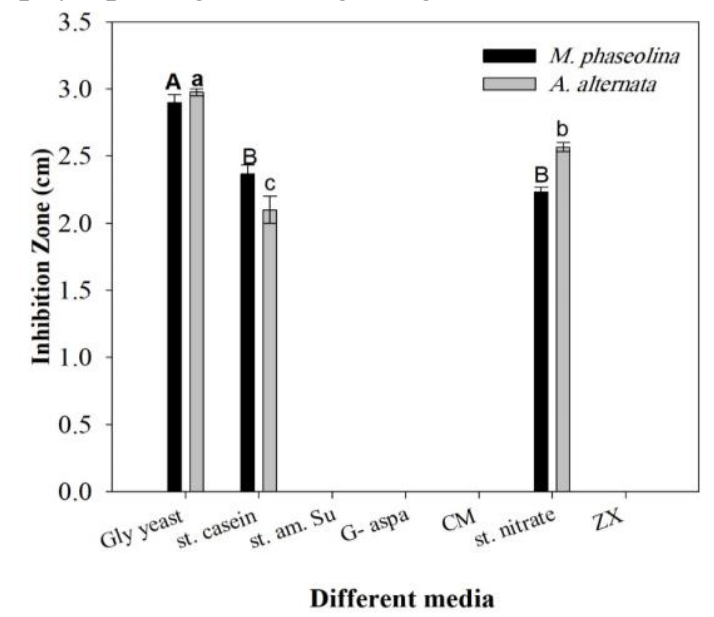

Fig. 1. Effect of different media on antifungal activity of Streptomyces gougeroti against Macrophomina phaseolina and Alternaria alternata

The time course of production of antifungal activity of Streptomyces gougeroti against Macrophomina phaseolina and Alternaria alternata started from the 3rd day then increased significantly to the maximum activity in 4th day $(3.5 \pm 0.11 \mathrm{~cm}$ and $4.87 \pm 0.24 \mathrm{~cm})$ respectively. The intracellular protein content started from the $3 \mathrm{rd}$ day then increased significantly to the maximum growth in the 4th day $(3.04 \pm 0.08 \mathrm{mg} / \mathrm{ml}$ ) (Figure $2 \mathrm{~A} \& \mathrm{~B}$ ). 


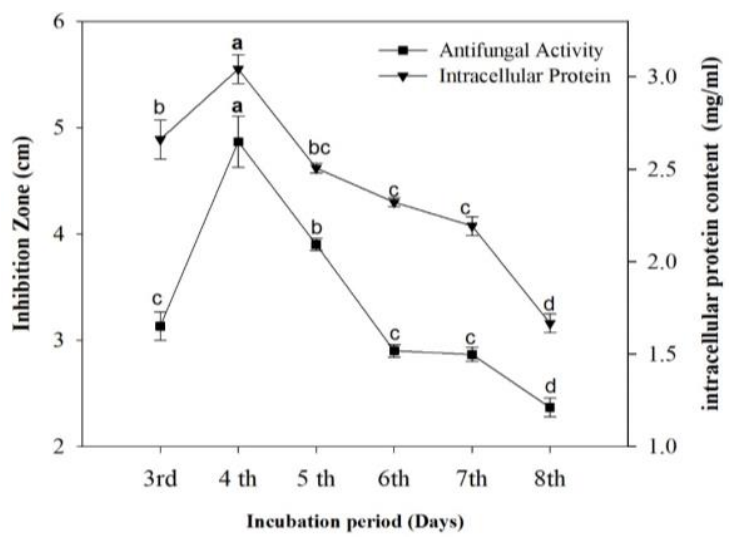

Figure 2.A. Effect of incubation period on antifungal activities and intracellular protein content of Streptomyces gougeroti against A. alternata

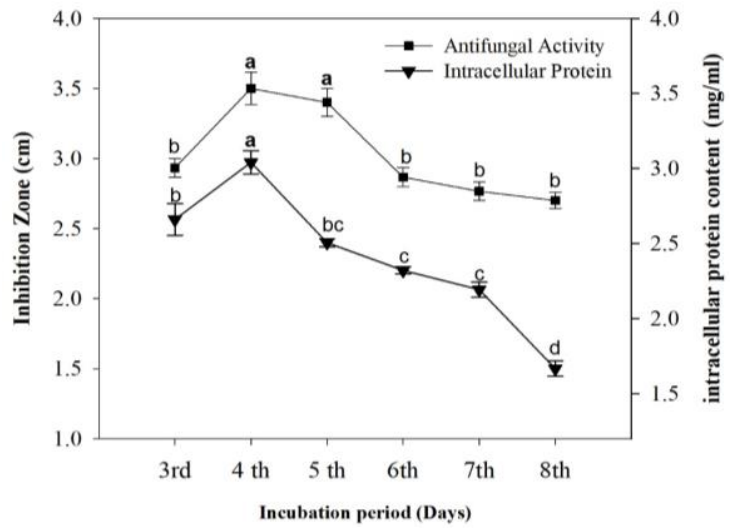

Figure 2.B. Effect of incubation period on antifungal activities and intracellular protein content of Streptomyces gougeroti against M. phaseolina

Antifungal activity of Streptomyces gougeroti against Macrophomina phaseolina and Alternaria alternata started from $\mathrm{pH} 6$ then increased significantly to the maximum activity at pH $6.5(3.67 \pm 0.09 \mathrm{~cm}, 3.90 \pm 0.06 \mathrm{~cm})$. The intracellular protein content stared from the $\mathrm{pH}$ 5 then increased significantly to the maximum growth at $\mathrm{pH} 6.5(3.20 \pm 0.20 \mathrm{mg} / \mathrm{ml})$ (Figure 3 A \&B).

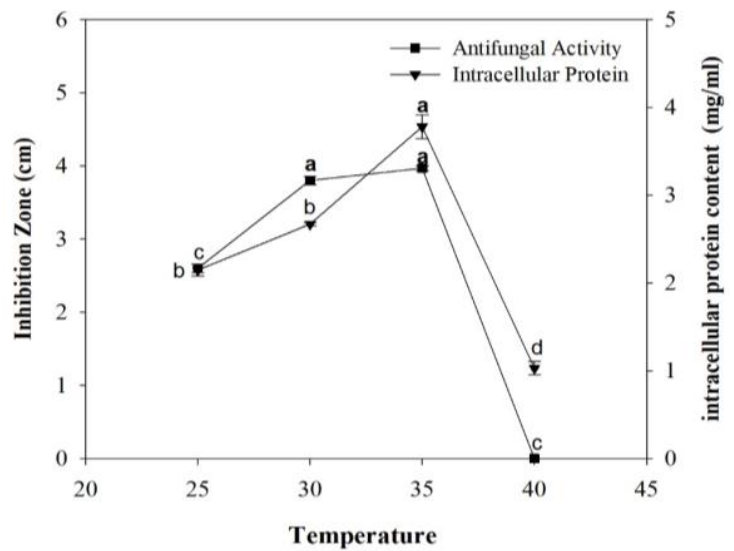

Figure 3.A. Effect of temperatures on antifungal activities and intracellular protein content of Streptomyces gougeroti against A. alternata

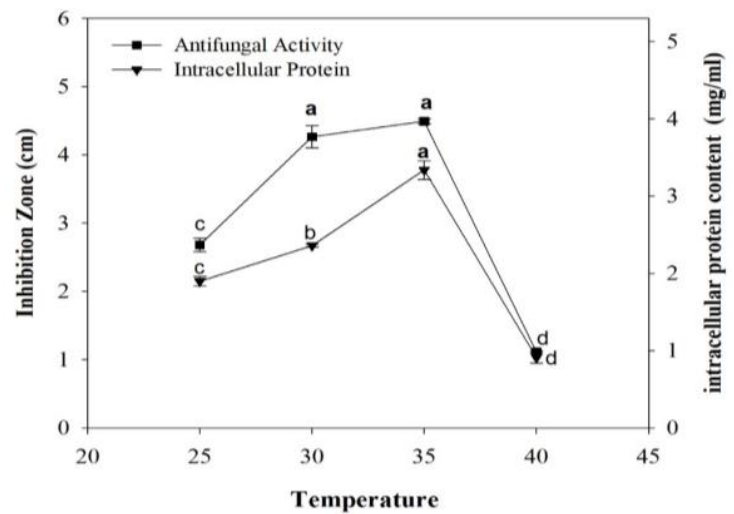

Figure 3.B. Effect of temperatures on antifungal activities and intracellular protein content of Streptomyces gougeroti against M. phaseolina

The antifungal activity against Macrophomina phaseolina and Alternaria alternata increased from $25^{\circ} \mathrm{C}$ to $35^{\circ} \mathrm{C}$ with optimum temperature at $35^{\circ} \mathrm{C}(4.00 \pm 0.03 \mathrm{~cm}$ and $3.96 \pm 0.03 \mathrm{~cm})$ respectively, then sharply decreased by increasing temperature at $40^{\circ} \mathrm{C}$. The intracellular protein started at $25^{\circ} \mathrm{C}$ then increased significantly to the maximum temperature at $35{ }^{\circ} \mathrm{C}(3.80 \pm 0.14 \mathrm{mg} / \mathrm{ml})$ (Figure 4 A \& B).

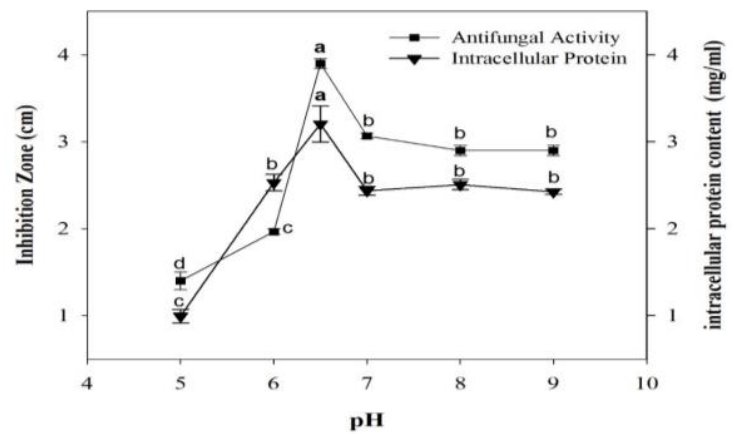

Fig. 4.A. Effect of $\mathrm{pH}$ on antifungal activities and intracellular protein content of Streptomyces gougeroti against $A$. alternata

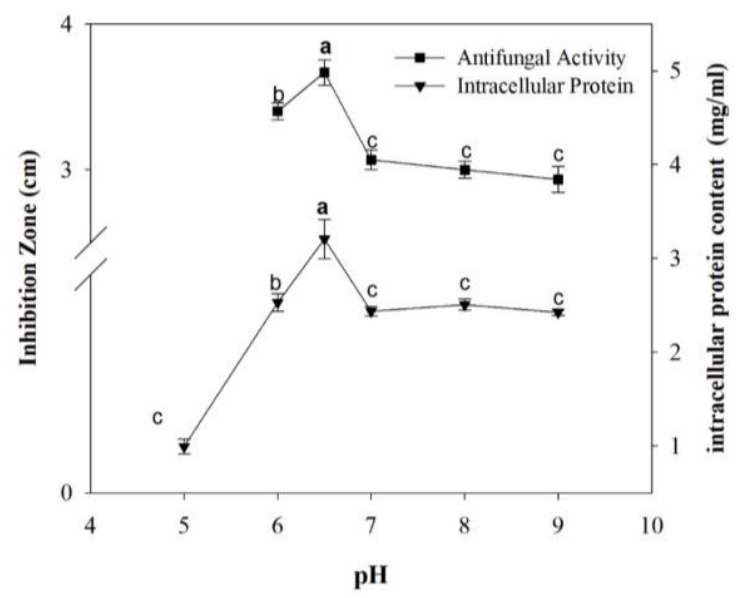

Figure 4.B. Effect of $\mathrm{pH}$ on antifungal activities and intracellular protein content of Streptomyces gougeroti against $M$. phaseolina 
The highest antifungal activity of Streptomyces gougeroti against Macrophomina phaseolina and Alternaria alternata was observed in presence of glycerol $(3.93 \pm 0.07 \mathrm{~cm}, 4.00 \pm$ $0.06 \mathrm{~cm}$ ). Colloidal chitin and cellulose had the minimum antifungal activity. The maximum intracellular protein content in presence of glycerol was $4.15 \pm 0.05 \mathrm{mg} / \mathrm{ml}$. (Figure $5 \mathrm{~A} \&$ B).

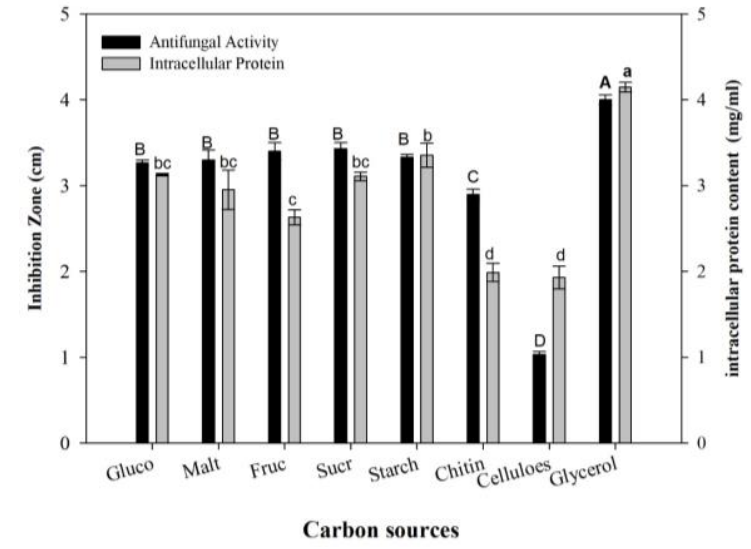

fig 5. A. Effect of different carbon sources on antifungal activities and intracellular protein content of Streptomyces gougeroti against A. alternata

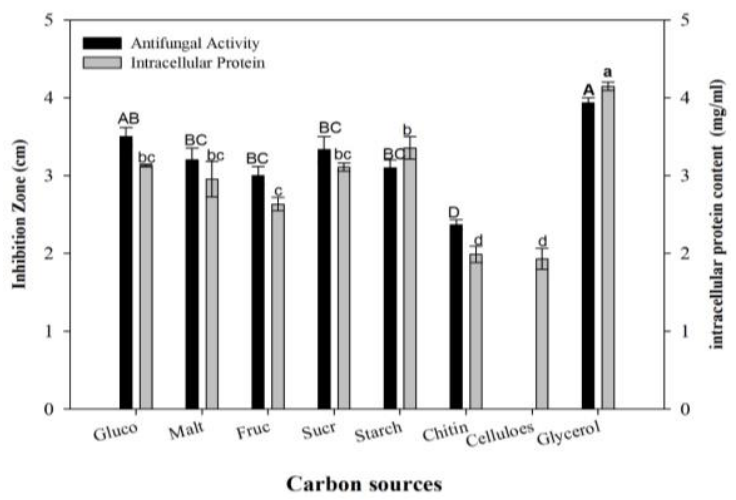

Fig 5. B. Effect of different carbon sources on antifungal activities and intracellular protein content of Streptomyces gougeroti against M. phaseolina

The highest antifungal activity against Macrophomina phaseolina and Alternaria alternata were recorded when beef extract was used as the nitrogen sources $(4.16 \pm 0.09 \mathrm{~cm}$ and $4.56 \pm 0.03 \mathrm{~cm}$ respectively).

The maximum intracellular protein content of Streptomyces gougeroti was occured in presence of beef extract $(3.46 \pm 0.03 \mathrm{mg} / \mathrm{ml})$. Casein could not stimulate the growth of Streptomyces gougeroti (Figure 6 A \& B).

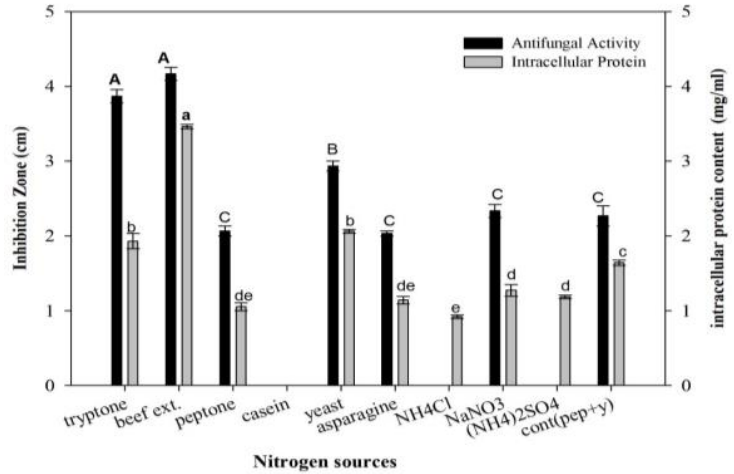

Fig 6.A. Effect of different nitrogen sources on antifungal activities and intracellular protein content of Streptomyces gougeroti against A. alternata

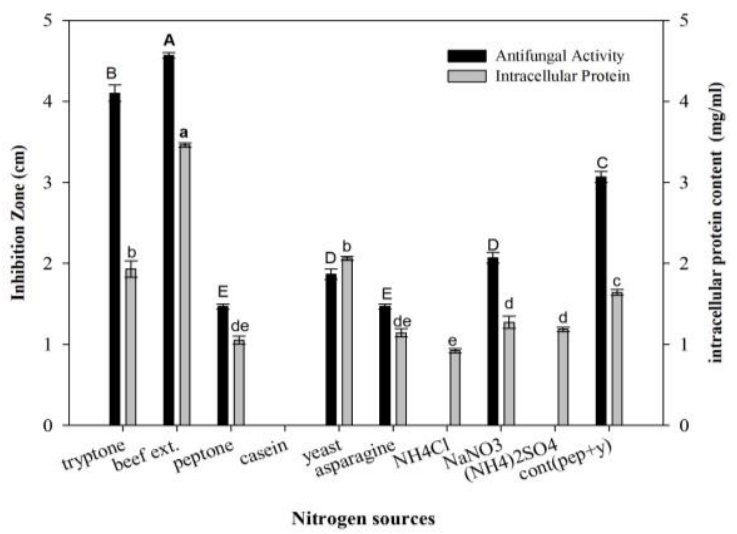

Fig 6.B. Effect of different nitrogen sources on antifungal activities and intracellular protein content of Streptomyces gougeroti against M. phaseolina

\section{Discussion}

Biological screening of Streptomyces sp. is carried out throughout the world for the determination of their antifungal activity (Bressan and Figueiredo 2003; Cao et al. 2005; Bonaldi et al. 2014 and Zhang et al. 2020 ). This study was performed to isolate and screen Streptomyces isolates from soil possessing antifungal activities and optimize their antifungal activities.

Starch nitrate agar medium used for isolation of Streptomyces sp. from soil samples (El-Naggar 2015; Atta et al. 2009; El-Naggar et al. 2009; Korayem et al. 2015). Also, Starch-casein agar medium was used to isolate actinomycetes (El Karkouri et al. 2019; Hasani et al. 2014). Some Streptomyces isolates could grow on glycerol yeast-extract agar media (Bawazir et al. 2018; Duddu and Guntuku 2016).

Production of antifungal activity from Streptomyces gougeroti against Alternaria alternata and Macrophomina phaseolina increased reaching maximum values after four 
days, after that, the production of antifungal activity was decreased. This result is similar to that of Abdelwahed et al., (2012) and Singh et al. (2017) who reported that antimicrobial activity of Streptomyces sp. against Macrophomina phaseolina, Fusarium oxysporum, Colletotrichum truncatum and Rhizoctonia solani was after four days. In this study, Streptomyces gougeroti showed maximum antifungal activity at $35{ }^{\circ} \mathrm{C}$. The present result was agreed with James et al. (1991); Sajid et al. (2011) and Bundale et al. (2015) who reported that Streptomyces thermoviolaceus, Streptomyces malachitofuscus and Streptomyces coeruleorubidus showed maximum antifungal activity at $35^{\circ} \mathrm{C}$. The highest yield of antifungal activity of Streptomyces gougeroti was when $\mathrm{pH}$ of the medium was from 6.5 to 7.0. This result is in accordance with Khair (2011) and Sajid et al. (2011) for Streptomyces malachitofuscus against Candida albicans and Mucor miehei.

The best carbon source for production of antifungal activity from Streptomyces gougeroti against Alternaria alternata and Macrophomina phaseolina was glycerol. This result is in agreement with that obtained by Grahovac et al. (2014) and Hasani et al. (2014). Glucose is certainly one of the best sources of carbon in the medium for antifungal production, this result is similar to Tarhan et al. (2011) and Khair (2011). On the other hand, maltose and sucrose showed the highest antifungal activity from Streptomyces albidoflavus against Rhizoctonia solani Islam et al. (2009) and Laidi et al. (2008). The optimal production of antifungal activity from Streptomyces gougeroti against Alternaria alternata and Macrophomina phaseolina were obtained when beef extract used as nitrogen source as recorded by Oskay (2011). Organic sources of nitrogen as peptone, yeast extract, and soybean meal gave better antifungal activity than other inorganic sources (Mitrović et al. 2017). In contrast to these results, maximum antimicrobial activity was obtained in culture supplemented with asparagine and potassium nitrate as nitrogen sources according to Thakur et al. (2009).

\section{References}

Abussaud M, Alanagreh L, Abu-Elteen K (2013) Isolation, characterization and antimicrobial activity of Streptomyces strains from hot spring areas in the northern part of Jordan, African Journal of Biotechnology, 12:7124-7132.

Al-Garni SM, Sabir JSM, El Hanafy A, Kabli SA, Al-Twiley DA, Ahmed MM (2014) Isolation and identification of antimicrobial Actinomycetes strains from Saudi environment, Journal of Food, Agriculture \& Environment, 12:1072-1079.

Atta H, Dabour S, Desoukey S (2009) Sparsomycin antibiotic production by Streptomyces sp. AZNIOFD1: taxonomy, fermentation, purification and biological activities. J. Agric. Environ. Sci, 5:368-377.

Bawazir AMA, Shivanna GB, Shantaram M (2018) Impact of Different Media for Growth and Production of Different Soluble Pigments in Actinomycetes Isolated from Soils of Hadhramout, Yemen. European Journal of Biomedical, 5:615-619.

Bhosale H, Kadam T, Mirajgave R, Holkar S (2018) Optimization and characterization of antifungal metabolite from a soil actinomycete Streptomyces indiaensis SRT1 . Indian Journal of Biotechnology, 17:261:271.

Bonaldi M, Kunova A, Saracchi M, Sardi P, Cortesi $\mathrm{P}$ ? Streptomycetes as biological control agents against basal drop. In: VIII International Symposium on Chemical and Non-Chemical Soil and Substrate Disinfestation, 1044: 313-318.

Bradford MM (1976) A rapid and sensitive method for the quantitation of microgram quantities of protein utilizing the principle of protein-dye binding. Analytical Biochemistry, 72:248-254

Bressan W, Figueiredo J (2003) Controle de Fusarium moniliforme em sementes de milho por actinomicetos. Embrapa Milho e SorgoComunicado Técnico (INFOTECA-E),65:1-4.

Budi S, Van Tuinen D, Arnould C, Dumas-Gaudot E, Gianinazzi-Pearson V, Gianinazzi S (2000) Hydrolytic enzyme activity of Paenibacillus sp. strain B2 and effects of the antagonistic bacterium on cell integrity of two soil-borne pathogenic fungi. Applied Soil Ecology. 15:191199.

Bundale S, Begde D, Nashikkar N, Kadam T, Upadhyay A (2015) Optimization of culture conditions for production of bioactive metabolites by Streptomyces spp. isolated from soil. Advances in Microbiology, 5:441.

Cao L, Qiu Z, You J, Tan H, Zhou S (2005) Isolation and characterization of endophytic streptomycete antagonists of Fusarium wilt pathogen from surface-sterilized banana roots. FEMS Microbiology Letters. 247:147-152.

Crawford DL, Lynch JM, Whipps JM, Ousley MA (1993) Isolation and characterization of actinomycete antagonists of a fungal root pathogen. Appl. Environ. Microbiol. 59:3899- 
3905.

Duddu MK, Guntuku G (2016) Isolation, screening and characterization of antibiotic producing actinomycetes from Kapuluppada plastic waste dumping yard, Visakhapatnam International journal of pharmacy and pharmaceutical sciences $8: 221-229$

El-Naggar MY, El-Assar SA, Abdul-Gawad SM (2009) Solid-state fermentation for the production of meroparamycin by Streptomyces sp. strain MAR01. Journal of Microbiology and Biotechnology. 19:468-473.

El-Naggar N (2015) Isolation, screening and identification of actinobacteria with uricase activity: Statistical optimization of fermentation conditions for improved production of uricase by Streptomyces rochei NEAE-25, Int. J. Pharmacol, 11:644-658.

El-Tarabily KA (2006) Rhizosphere-competent isolates of streptomycete and non-streptomycete actinomycetes capable of producing cell-walldegrading enzymes to control Pythium aphanidermatum damping-off disease of cucumber. Botany, 84:211-222.

El Karkouri A, Assou SA, El Hassouni M (2019) Isolation and screening of actinomycetes producing antimicrobial substances from an extreme Moroccan biotope. The Pan African Medical Journal. 33:1-9.

Ganesan P, Reegan AD, David RHA, Gandhi MR, Paulraj MG, Al-Dhabi NA, Ignacimuthu S (2017) Antimicrobial activity of some actinomycetes from Western Ghats of Tamil $\mathrm{Nadu}$, India Alexandria. journal of medicine. 53:101-110.

Gatto MA, Ippolito A, Linsalata V, Cascarano NA, Nigro F, Vanadia S, Di Venere D (2011) Activity of extracts from wild edible herbs against postharvest fungal diseases of fruit and vegetables Postharvest, Biology and Technology, 61:72-82.

Giraud T, Gladieux P, Gavrilets S (2010) Linking the emergence of fungal plant diseases with ecological speciation, Trends in ecology \& evolution. 25:387-395.

Grahovac J, Grahovac M, Dodić J, Bajić B, Balaž J (2014) Optimization of cultivation medium for enhanced production of antifungal metabolites by Streptomyces hygroscopicus, Crop Protection. 65:143-152.

Hasani A, Kariminik A, Issazadeh K (2014) Streptomycetes: characteristics and their antimicrobial activities. International Journal of Advanced Biological and Biomedical Research , 2: 63-75

Islam MR, Jeong YT, Ryu YJ, Song CH, Lee YS (2009) Isolation, identification and optimal culture conditions of Streptomyces albidoflavus C247 producing antifungal agents against Rhizoctonia solani AG2-2, Mycobiology, 37:114-120.

Johnson, L.F., Curl, E.A., Bond, J.H. \& Fribourg, H.A. (1959). Methods for studying soil microflora: plant disease relationships. Minnesota, US: Burgess Publishing, pp: 15.

Khair A (2011) In vitro antifungal activity of Streptomyces spororaveus RDS28 against some phytopathogenic fungi. African Journal of Agricultural Research, 6:2835-2842.

Kishore GK, Pande S, Podile A (2005) Biological control of late leaf spot of peanut (Arachis hypogaea) with chitinolytic bacteria. Phytopathology, 95:1157-1165.

Korayem A, Abdelhafez A, Zaki M, Saleh E (2015) Optimization of biosurfactant production by Streptomyces isolated from Egyptian arid soil using Plackett-Burman design. Annals of Agricultural Sciences, 60:209-217.

Laidi RF, Sifour M, Sakr M, Hacene H (2008) A new actinomycete strain SK4-6 producing secondary metabolite effective against methicillin-resistant Staphylococcus aureus. World Journal of Microbiology and Biotechnology, 24:2235-2241.

Lee S-O, Choi G-J, Choi Y-H, Jang K-S, Park D-J, Kim C-J, Kim J-C (2008) Isolation and characterization of endophytic actinomycetes from Chinese cabbage roots as antagonists to Plasmodiophora brassicae. J. Microbiol, Biotechnol, 18:1741-1746.

Liu D, Anderson NA, Kinkel LL (1995) Biological control of potato scab in the field with antagonistic Streptomyces scabies. Phytopathology, 85:827-831.

Martinez JA (2012) Natural fungicides obtained from plants. In: Fungicides for plant and animal diseases. IntechOpen .

Mitrović IŽ, Grahovac JA, Dodić JM, Dodić SN, Grahovac MS (2017) Effect of nitrogen sources on the production of antifungal metabolites by Streptomyces hygroscopicus .Zbornik Matice srpske za prirodne nauke:183-191.

Nega A (2014) Review on concepts in biological control of plant pathogens. Journal of Biology, Agriculture and Healthcare $\square$ 4:33-54.

Oskay M (2011) Effects of some Environmental Conditions on Biomass and Antimicrobial Metabolite Production by Streptomyces Sp., KGG32. International Journal of Agriculture \& Biology, 13:317-324.

Prapagdee B, Kuekulvong C, Mongkolsuk S (2008) Antifungal potential of extracellular metabolites produced by Streptomyces hygroscopicus against phytopathogenic fungi, International Journal of Biological Sciences, 4:330:340. 
Rabah FL, Elshafei A, Saker M, Cheikh B, Hocine $\mathrm{H}$ (2007) Screening, isolation and characterization of a novel antimicrobial producing actinomycete, strain RAF10. Biotechnology, 6:489-496.

Sajid I, Shaaban KA, Hasnain S (2011) Identification, isolation and optimization of antifungal metabolites from the Streptomyces Malachitofuscus ctf9. Brazilian Journal of Microbiology, 42:592-604

Sharma N, Sharma K, Gaur R, Gupta V (2011) Role of chitinase in plant defense. Asian J Biochem 6:29-37.

Sharma R, Singh D, Singh R (2009) Biological control of postharvest diseases of fruits and vegetables by microbial antagonists: A review Biological control 50:205-221.

Singh C, Parmar RS, Jadon P, Kumar A (2017) Optimization of Cultural Conditions for Production of Antifungal Bioactive Metabolites by Streptomyces spp. Isolated from Soil. International Journal of Current Microbiology and Applied Sciences, 6:386-396.

Sousa CdS, Soares ACF, Garrido MdS (2008) Characterization of streptomycetes with potential to promote plant growth and biocontrol. Scientia Agricola, 65:50-55.

Strange RN, Scott PR (2005) Plant disease: a threat to global food security, Annual review of phytopathology, 43:83-116.

Tarhan L, Kayalı HA, Sazak A, Şahin N (2011) The correlations between TCA-glyoxalate metabolite and antibiotic production of Streptomyces sp. M4018 grown in glycerol, glucose, and starch mediums, Applied biochemistry and biotechnology, 164:318-337.

Thakur D, Bora T, Bordoloi G, Mazumdar S (2009) Influence of nutrition and culturing conditions for optimum growth and antimicrobial metabolite production by Streptomyces sp. 201. Journal de Mycologie Medicale, 19:161-167.

Tripathi P, Dubey N, Shukla A (2008) Use of some essential oils as post-harvest botanical fungicides in the management of grey mould of grapes caused by Botrytis cinerea. World Journal of Microbiology and Biotechnology, 24:39-46

Waksman SA (1961) The Actinomycetes, classification, identification and description of genera and species. vol 2 Williams \& Wilkins Company Baltimore, MD 363pp.

Waksman SA (1959) Strain specificity and production of antibiotic substances .X. characterization and classification of species within the Streptomyces Griseus. Group Proceedings of the National Academy of Sciences of the United States of America 45:1043.

Williams PG (2009) Panning for chemical gold: marine bacteria as a source of new therapeutics, Trends in biotechnology, 27:45-52

You M, Sivasithamparam K, Kurtböke D (1996) Actinomycetes in organic mulch used in avocado plantations and their ability to suppress Phytophthora cinnamomi. Biology and Fertility of Soils, 22:237-242.

Zain ME (2011) Impact of mycotoxins on humans and animals. Journal of Saudi Chemical Society, 15:129-144.

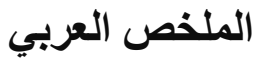

\title{
عنوان البحث : الظروف المثلى لاستربتوميسس جوجيرتى كعوامل تحكم بيولوجية محتملة ضد مسببات الأمر اض الفطرية للنباتات الطرو الفئر
}

\author{
محمد أبو دبارة'، أميرة الفلال'، محمد موسى'، ايناس شعبان' \\ ' كلية العلوم جامعة دمياط قسم النبات والميكروبيولوجي
}

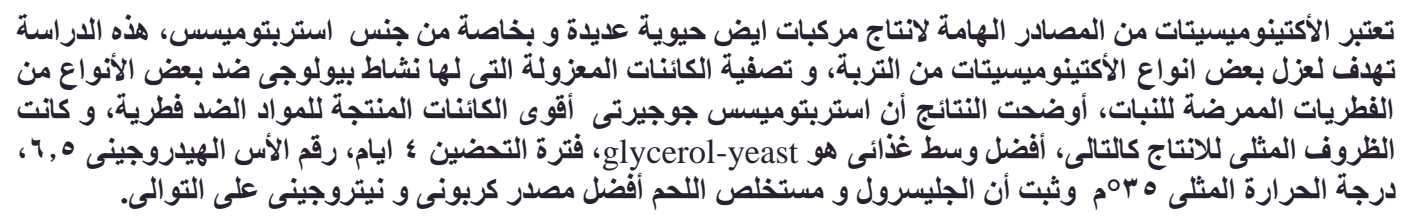

